International Journal for Crime, Justice and Social Democracy

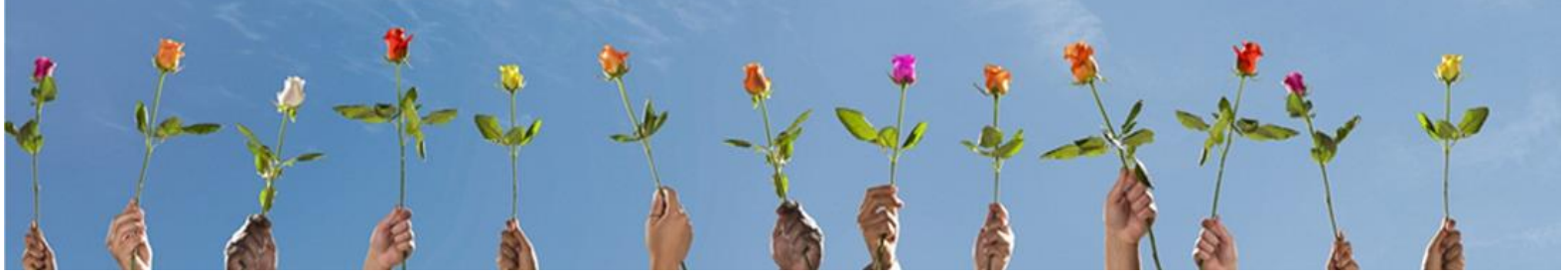

\title{
The Carceral Automaton: Digital Prisons and Technologies of Detention
}

\author{
Carolyn McKay \\ The University of Sydney, Australia
}

\begin{abstract}
Prisons are on the cusp of a technological transformation as twenty-first-century digital connectivity in 'free' society permeates prison design and offender management. This article will begin with an overview of the digital technologies in 'smart' prisons. Two limbs are emerging: technologies that are embedded into the infrastructure of prisons to benefit authorities through heightened security, and technologies that may benefit prisoners by providing them with positive opportunities to access justice, maintain family relationships and engage in programs aimed at optimising their post-release circumstances and rehabilitation. However, recent case law paints a picture of prison life devoid of human contact during the COVID-19 pandemic, bringing isolation and heightened anxiety. Through the lens of emergent conceptions of digital criminology, this article will analyse Australian case law to examine whether the automated, smart or digital prison offers a utopian vision of safe detention and rehabilitation or a dehumanised and punitive dystopia.
\end{abstract}

\section{Keywords}

Smart prisons: digital technologies; prisoners; rehabilitation; coronavirus jurisprudence.

Please cite this article as:

McKay C (2022) The carceral automaton: Digital prisons and technologies of detention. International Journal for Crime, Justice and Social Democracy 11(1): 100-119. https://doi.org/10.5204/ijcjsd.2137

Except where otherwise noted, content in this journal is licensed under a Creative Commons Attribution 4.0 International Licence. As an open access journal, articles are free to use with proper attribution. ISSN: 2202-8005 


\section{Introduction}

Prisons are on the cusp of a technological transformation as twenty-first-century digital engagement and connectivity in 'free' society permeate prison design and offender management. Automation, robotics, artificial intelligence (AI), facial recognition and data analytics are just some of the new technologies being deployed and embedded into the infrastructure of prisons in many countries.

This article will begin with a global overview of the digital technologies of detention. Two limbs are emerging in the development of automated or 'smart' prisons: technologies that benefit prison authorities through heightened security and surveillance (see, e.g., Kaun and Stiernstedt 2020; Simon 2013) and technologies that may directly benefit people in prison and their rehabilitation while indirectly benefiting prison management (see, e.g., Jewkes and Reisdorf 2016; Knight and Van De Steene 2017; McKay 2018a). Regarding the first limb, as prison populations grow, forms of digital detention technologies promise safer, hands-free and cheaper modes of offender management, integrated with vast databases and networked with other justice agencies. The fully automated prison, what I refer to as the carceral automaton-an efficient, high-tech apparatus of imprisonment-reduces the need for prison officers to interact with prisoners physically. An array of new digital technologies can track, sense, record and analyse prisoners' movements and identities, monitor and predict their behaviour, capture data (including biometrics and health) and regulate reward systems and environmental conditions.

As to the second limb, there are technologies that promise to benefit people in prison by providing safer and more rehabilitative environments and connecting them to the outside world-their families, lawyers, health providers, education and reintegration and rehabilitation services. These technologies, including audio/audiovisual links and in-cell digital tablets, may provide prisoners with positive opportunities to access justice, maintain family relationships and engage in programs aimed at optimising their postrelease circumstances, ultimately facilitating rehabilitation and reducing recidivism. Significantly, the provision of personal digital devices in prisons may normalise technologies and ensure that prisoners do not remain digitally excluded when they re-enter society. On this point, this article will build on the author's prior case law research and analysis of prisoners' 'rights' to digital devices and their use of audiovisual link technologies (McKay 2018a, 2018c).

However, with a focus on Australia, case law from 2020 has painted a picture of prison life without physical visits by families or lawyers: contact visits were replaced by technologies. The World Health Organization declared COVID-19 a global pandemic on 11 March 2020, and prisons, as renowned 'epicentres for infectious diseases' (DPP v Calgaret: Sexton J, para 42), necessarily adopted preventive measures to reduce the risk of viral infections among staff and prisoners (see, e.g., Astbury v R). Social visits, in particular, were targeted while lawyers were pressed to undertake legal conferencing using audiovisual links or telephones (Guest v DPP; Rakielbakhour v DPP). Prison authorities sought to address the effects of suspending visits by encouraging the use of telephones ( $\mathrm{R} v$ Despotovski) and traditional mail and by implementing alternative arrangements through the increased use of 'video visits' and an email prisoner service (Guest v DPP). During the pandemic, authorities in New South Wales (NSW) commenced the distribution of personal digital tablets to prisoners to facilitate greater virtual family contact, among other purposes (Fitzgerald 2020).

Nevertheless, the hardships, high anxiety levels and increased isolation inflicted on prisoners by the visitor lock-out and the implication for human rights have been acknowledged by courts and well documented in the emergent Australian 'coronavirus jurisprudence' (Judicial College of Victoria n.d.). As noted by Haesler SC DCJ in R v Despotovski: para 39, 'the lack of visits reducing any capacity to remain in contact with pro-social friends and family, and that heightened anxiety and concerns, are relevant factors that must be synthesised along with all other matters [in sentencing]'. Therefore, this body of coronavirus jurisprudence provides a glimpse of the effects of reducing or eliminating human contact with prisoners. Analysing this case law produces new knowledge regarding the increasing digitalisation of prisons and, collectively, forewarns of a speculative future where human contact is completely replaced by smart prison technologies. 
Through the lens of digital criminology, a theoretical framework that goes beyond the narrow conventions of cyber criminology, this article will evaluate the automated smart digital prison. Developed from Lupton's $(2012,2014)$ digital sociology, digital criminology was defined by Smith, Bennett Moses and Chan (2017: 263) as concerning 'itself conceptually, methodologically and empirically with the task of understanding how digital devices/data are mediating experiences, impressions and processes of crime/crime control in familiar and strange ways'. Building on this, Tangen (2018: np, emphasis in original) explained digital criminology as:

- 'an object of criminological focus

- a medium through which criminology is 'performed'

- a subjectivity for organising our understanding and approach to emerging technologies in the criminal justice system'.

Digital criminology recognises, as its starting point, that we exist in a digital society in which technologies are embedded in daily existence, our online (virtual) and offline (terrestrial) realities are integrated (Powell, Stratton and Cameron 2018), and citizens can be considered digital subjects (Krasmann 2017). Powell, Stratton and Cameron (2018) argued that digital technologies are enmeshed in everyday life and social and legal structures to such an extent that technologies largely go unnoticed. In this way, technologies can seem benign (McKay 2018c). With its broad, interdisciplinary techno-social approach, digital criminology surpasses the limitations of traditional conceptions of cyber criminology to provide a reflective and critical framework for understanding the profound changes across the entire criminal justice system. The term 'cyber', much used in the 1990s, is somewhat outdated and fails to encompass the mobility and ubiquity of electronic devices (Lupton 2012). 'Digital', according to Powell, Stratton and Cameron (2018: 7), "better encapsulates both the "old" notions of cyber and contemporary shifts and advances in technology and sociality'.

As a form of theoretical inquiry, digital criminology entwines cultural, legal and political aspects of twentyfirst-century digital society and enables an analysis of not only offending and policing but also victimisation, resistance and forms of social harm that may fall short of criminalisation. It is also a frame through which we can perform a contemporary analysis of risk, control and surveillance-issues intimately connected with incarceration. In this way, digital criminology extends beyond a mere consideration of cyber perpetration and cyber investigation and, instead, allows the interrogation of the techno-social forces at work in several justice contexts, including regimes of punishment and detention. This approach responds to calls from scholars such as Hayward (2012) to broaden theoretical engagements, extend narrow conventional cyber crime precepts and recognise the environmental, spatial and techno-social aspects. In particular, I argue that digital criminology provides a means to critique the perceived or assumed neutrality of smart prison technologies; there continues to be a fraught relationship between humans and technologies (Wood 2021), especially concerning opaque automated decisionmaking and the uncanniness of robots. These tensions are accentuated when we examine the incursion of such technologies into closed carceral environments. Smith, Bennett Moses and Chan (2017: 260) observed that, the increasing use of digitisation and datafication of the criminal justice system is 'radically altering traditional modes' of all practices, from policing through to managing correctional facilities.

With this digital criminological framework, this article will examine whether the automated digital prison offers a utopian vision of safe punishment, connectivity and rehabilitation, an objectionable and oppressive dehumanised dystopia that further encloses the already-closed environment of prison, or something in-between. Smart prisons are being rolled out around the world; thus, this is a significant area to research, given that, as Kaun and Stiernstedt (2019) have observed, related scholarly literature is almost non-existent. Moreover, because the embedding of smart technologies into prisons is seemingly being driven by the commercialisation of prisoner communications (Kerr and Willis 2018) and profit-seeking, multinational prison technology vendors (Jefferson 2020) with vulnerable incarcerated populations being the target consumers, this is an issue worthy of critical and ethical analysis. Profit-making in communication services provided to 'the (literally) captive market' of people in prison has been a 
contentious issue since the introduction of prison phones (Jackson 2005: 269). The argument is that the rate of digitalisation accelerated during the pandemic, increasing prison automation and dehumanisation, and reinforcing the prison-industrial complex.

\section{The Smart Prison and Digital Technologies of Detention}

The digitisation of general society, commencing during the late twentieth century and accelerating in recent decades, means that internet access and digital technology are prerequisites for an array of government, welfare, employment, housing, education, health, media, financial and business services (Powell, Stratton and Cameron 2018). Increasingly, our social interactions are mediated and facilitated by various electronic devices, apps and online platforms. While technologies have been incrementally adopted by law enforcement, court, legal profession and corrections services, the criminal justice system has been suitably cautious about embracing digital transformation given the longstanding and fundamental principles of procedural justice and, in some jurisdictions, human rights. However, the notion of digital justice (Byrom 2019; Donoghue 2017; McKay 2020a, 2021) has been gaining traction and recognises the gradual integration of technologies in everyday life, concomitant move away from face-toface legal encounters and shift towards remote hearings, e-trials and virtual courts (Mulcahy and Rowden 2019). Criminal practices, procedures and evidence have been moving from physical to digital formats (McKay 2018b) such that a prosecution brief is now measured in 'multiple terabytes of computer database space' (The State of Western Australia v Edwards: Hall J, paras 4, 160).

As will be discussed later, the COVID-19 pandemic precipitated further major digital changes in the essential services provided by criminal courts and criminal justice agencies such as corrections. When emergency health orders ${ }^{1}$ required physical courts to close and prisons to lockdown, there was a very sudden pivot to digital justice to keep the wheels of justice turning (Rakielbakhour v DPP; Rossner and McCurdy 2020). Central to digital justice is the network of audiovisual link technologies that connect disparate criminal justice spaces, including courtrooms, prison video link studios, police cells and legal profession offices. These communication technologies have greatly reduced the need for prisoners to be transported to/from courts and replaced in-person legal conferencing (McKay 2018c).

Even before the COVID-19 pandemic, prisons in many countries were gradually introducing new technologies for security, surveillance and efficient inmate management and to address prisoners' rehabilitation and recidivism, giving rise to the concept of the smart prison and processes of 'smartification'. These recent technological changes are a continuation of the prison-industrial complex (Jackson 2005).

The smart prison can be understood as a natural extension of technological smartness in general society, particularly in urban planning: Kaun and Stiernstedt (2020) argued that the concept of the smart city privileges the embedding of information and communication technologies (ICT) into the networked infrastructures of cities to promote smart economies and sustainability, among other goals. While connectivity and smart living benefit citizens, Kaun and Stiernstedt (2020:1583) also suggested that 'smart cities are ... data cities' enabling the possible harvesting of vast quantities of the inhabitants' data and, thus, mass surveillance. Indeed, Jefferson (2020) argued that the proliferation of networked technologies throughout smart cities represents the diffusion and digitisation of carceral power. With this in mind, it is unsurprising that the processes of smartification and digital transformation (Knight and Van De Steene 2017; Van De Steene and Knight 2017) are being integrated into the social realms of prisons. It is as if Foucauldian carceral power (Foucault 1977) escaped the analogue prison, became digitised by free society and is now being fed back into the apparatus of the smart prison.

However, there are unique tensions in the prison context relating to 'control and rehabilitation; punishment and empowerment ... [and] access and disconnection' (Kaun and Stiernstedt 2020: 1583). Overlaid are pressing carceral concerns regarding risk, security and surveillance. These issues are further tested when considering the competing purposes of incarceration: is it to protect society or for punishment, incapacitation, deterrence, rehabilitation or treatment? While the priorities of different 
prison authorities vary around the world, they generally centre on providing the 'safe, secure and humane management of prisoners' (NSW Auditor-General 2019: 1) and reducing reoffending. Additionally, it is critical to acknowledge that prisons usually hold pre-trial, bail-refused defendants alongside convicted offenders. The introduction of smart technologies requires a careful balancing of these concerns and the needs of different prison populations.

The term 'smart prison' is frequently used to describe contemporary prisons in which ICT and AI technologies are integrated into the infrastructure. Smart technology-enabled prisons seek to achieve a number of objectives such as: streamlining the work of prison officers and administrators; enabling smart surveillance through $\mathrm{AI}$, facial recognition and analytics; assisting prisoners with their re-entry into society; and, according to Knight and Van De Steene (2017), providing prisoners with a humane environment. Smart prisons, or some aspects thereof, have been introduced in many countries, including Australia (Goedbloed 2019), China (Chen 2019), Finland (Lindström and Puolakka 2020), Hong Kong (Leung 2019), Singapore (Paulo and Tanu 2019), Taiwan (Yang 2020), Turkey (Altay 2020) and the United States (US) (Francescani 2019). The following sections will provide an overview of select smart digital detention technologies and how they stand to benefit prison authorities and, in some instances, prisoners.

\section{Technologies of Security, Surveillance and Prison Population Management}

The rise of the smart prison, or 'technocorrections' (Leighton 2014: 4), can be understood from several angles: as a means to provide safer, hands-free and cheaper modes of offender management and prison administration; as a natural extension of society's increased aversion to risk; as a means to collect more comprehensive data regarding offenders to be networked with other justice agencies; and, finally, as a mode of increased security and control over prison populations.

\section{Safety and Security}

Prisons, punitiveness and technologies have always been closely connected (Hallsworth and Kaspersson 2017) with the digital realm providing new techniques of discipline and order, and some have suggested that prisons are 'testbeds' for new surveillance technologies (Kaun and Stiernstedt 2019: 4). Prisons can be volatile environments for prison officers and prisoners, with 'inmate on inmate, and inmate on staff assaults' (NSW Auditor-General 2019: 2) occurring particularly in overcrowded facilities. For example, for the year to March 2019 in England and Wales, there were 34,425 assault incidents and 10,311 assaults on staff (Ministry of Justice 2019; The POA n.d.). Dodd, Antrobus and Sydes (2020: 1191; see also Sydes, Dodd and Antrobus 2020) surveyed increasing prison violence in several countries and articulated the repercussions: for prisoners, 'victimization while in custody can cause further trauma, stifle rehabilitation efforts, and reduce cooperation with correctional staff due to damaged perceptions of procedural justice and legitimacy', while for prison officers, 'exposure to violence can exacerbate work stress, provide a catalyst for posttraumatic stress disorder, and lead to burnout'.

To counter such dangers, especially for correctional staff, smart prisons with automated, AI and/or robotic forms of monitoring and surveillance can reduce the need for prison officers to interact with prisoners physically, providing a safer work environment. For instance, 'robot wardens' with three-dimensional cameras, sensors and pattern recognition algorithms to identify irregular or inappropriate behaviours have been trialled in South Korea (Carbone 2011; Kim 2012) and Hong Kong (Leung 2019). These robots autonomously patrol the prison while supervised by a remote prison officer (Kim 2012). Robots are also being used to detect drugs in prisoners' faecal matter (Bala and Trautman 2019). In conjunction with enhanced closed-circuit television cameras, facial recognition technology, video analytics and tracking wristbands, prison authorities are aiming for smart systems of hyper security and surveillance (Leung 2019) and optimal orderly functionality (Jefferson 2020). Prison design in China has been described as heading for 'robotocracy' through using AI to control facilities (Chen 2019: np). China's 'smart jail', Yancheng Prison, provides continuous blanket surveillance of prisoners using a network of sensors and cameras connected to the AI 'brain' that can continuously track and monitor every inmate (Chen 2019: $\mathrm{np})$. 
The Singapore Prison Service (SPS) is developing a model of a 'prison without guards' using a combination of smart technologies (Yusof 2018) to achieve operational efficiencies by employing fewer prison officers (Ganesan 2018). It has been reported that five key technologies are being piloted or integrated (Khair 2018: np; see also Ganesan 2018):

1) AVATAR (advanced video analytics to detect aggression) - a human behaviour detection system for aggressive behaviours - and VADAR (video analytics to detect abnormal behaviour) to detect irregular activities and alert prison authorities;

2) facial recognition cameras in cells for automated muster checks;

3) scannable wrist tags with communication chips that enable prisoners to make cashless purchases at self-service vending machines. These are also connected to the digital rehabilitation records management system to track prisoners' attendance at rehabilitation programs and collect data;

4) shared digital tablet devices, known as the Digitisation of Inmate Rehabilitation and Corrections Tool, to provide apps for self-learning, study and communication, replacing hardcopy materials and reducing contraband; and

5) iKiosk, which enables prisoners to undertake a range of self-service tasks such as administrative requests and redeeming privileges.

In a high-tech jail in the Netherlands, radio-frequency identification (RFID) bracelets have been introduced, which operate as part of an integrated security management system to automate prison doors and monitor prisoners' movements and locations, in addition to automated emotion recognition software, which can monitor prisoners' conversations and conflicts (Northfield 2018; see also Kenis et al. 2010). Through a chip embedded in a tamper-resistant bracelet or anklet, RFID technology identifies and tracks prisoners and their compliance with their daily prison schedule, confirms headcounts or muster in perimeter control and exclusion zones and provides evidence of misconduct (Halberstadt and La Vigne 2011). These technologies are said to be more efficient than human monitoring and can free up time for prison officers to be more involved in high-level rehabilitation work (Yusof 2018). Leighton (2014: 6) argued that the use of RFID in Japanese prisons enables prisoners to move through the correctional facility unescorted but remain subject to intense surveillance, and this use is said to develop prisoners' autonomy and self-discipline. However, in terms of preventing violence, a study of RFID technologies in the US found that RFID was an ineffective deterrent to prisoner misconduct, specifically sexual violence (Halberstadt and La Vigne 2011).

Prison officers face a high-risk workplace (Sydes, Dodd and Antrobus 2020), therefore, safety is a key reason for introducing new technologies. While body-worn cameras have been increasingly used by law enforcement in many countries, the technology is now also being embraced by corrections services and, on the whole, supported by prison officers (Dodd, Antrobus and Sydes 2020). Body-worn cameras increase operational transparency and the ability to collect evidence during critical incidents such as riots, the use of force or contraband raids (Roberts 2020). How will future prison riots, violence and disturbances be controlled? At present, prison officers often resort to so-called less-lethal chemical aids (Lewer and Davison 2005), such as tear gas and pepper spray, and physical methods of restraint and weaponry, including handcuffs, batons and firearms. ${ }^{2}$ Recent 'rapid build prisons' with dormitory-style accommodation in NSW 'have the ability to deploy chemical agents from an elevated position with the use of gas insertion hatches' (Corrective Services of New South Wales 2017: 5; see also Barbour 2012; Corrective Services Administrators' Council 2018; McKay 2018b). Although, as discussed above, robots have been introduced into some prisons, there are currently no features that allow robots to restrain prisoners physically (Kim 2012). Bagaric, Hunter and Wolf (2018) controversially suggested that conducted energy devices could be used remotely in their model of technological incarceration to immobilise prisoners who are attempting to escape or commit crimes.

Contraband is a problem that a variety of technologies can address. Common contraband includes mobile phones (Grommon, Carter and Scheer 2018), illicit drugs and injecting equipment (Treloar, McCredie and Lloyd 2016), weapons, tools, money and tobacco; basically, anything that prison authorities determine is 
prohibited (Koslover et al. 2016). Contraband enters prisons concealed on or in visitors and staff, vehicles, mail, clothing and furniture (Russo and Wells 2019). In addition to traditional technologies such as X-rays, metal detectors and detection dogs, there are a number of emerging technologies for detecting contraband (Whitworth 2010) and dealing with new forms of delivery by uncrewed aircraft systems and the ensuing need for drone security (Craig, Russo and Shaffer 2016). Drone detection and deflector/blocking technologies can provide fully automated and remote surveillance of prison airspace to minimise the opportunities for contraband to enter prisons (Navtech Radar n.d.). Automated mail screening is essential to detect illicit substances (such as buprenorphine or 'bupe' strips; see Department of Communities \& Justice 2019) impregnated in letters and cards (Schweitzer et al. 2018). In Japan, drug detection is no longer conducted by degrading physical strip-searching; instead, a "sniffer" of "puffer" machine', akin to airport technology designed to detect explosives on civilian passengers, is used as well as a full-body imaging scanner system (Leighton 2014: 5).

It is clear from the above overview that prison smartification is leading to a form of hands-off, 'at-adistance monitoring' and 'digital rule' (Jones 2000: 5), or perhaps it will be an algorithmic rule-an internet of incarceration (Bagaric, Hunter and Wolf 2018) - or the rise of the 'robotocracy' (Chen 2019) or, I suggest, a carceral automaton. A digital criminological approach to these developments calls for an analysis of the ethical ramifications, underpinned by related concepts of managerialism (Jones 2000), technocratic justice (O'Malley 1984) and actuarial justice (Feeley and Simon 1994) that are entwined with theories of risk, probability, statistics, prevention and prediction (Beck 1992; Jones 2000). However, before dealing with the many ethical concerns, the explicit networking of digital technologies in corrections speaks to the " systemic" character of criminal justice' and the gathering and integration of data from multiple agencies (Jones 2000: 12). Smart prisons will generate, analyse and disseminate vast quantities of data about their inhabitants.

\section{Risk, Datafication and Surveillance}

The rise of the smart prison is closely connected to trends in risk assessments and datafication that structure many contemporary social institutions (Kaun and Stiernstedt 2019). In our risk society (Beck 1992), myriad aspects of social life are governed by risk assessments, predictions and management (Hannah-Moffat 2013). In criminal justice, the risk of (re)offending is now considered 'calculable' (Hannah-Moffat 2013: 129). Risk assessments routinely inform key decision points in the criminal justice system, including whether to grant bail to an accused person and during sentencing, parole hearings and community supervision (McKay 2020b). Actuarial and algorithmic risk assessments are critical in offender management regarding the security classification of prisoners, identifying prisoners' risks of harming themselves and others and their criminogenic needs (Jefferson 2020; McKay 2020b; The Law Society Commission on the Use of Algorithms in the Justice System and The Law Society of England and Wales 2019). Smart prisons evidence the integration of 'technologies of risk management' and 'precautionary technologies' (Simon 2013: 78-79) into penality. The criminal justice system's precautionary technologies are also being dispersed into the broader community via the increasing use of electronic monitoring (Gacek 2020; Jefferson 2020; Jones 2000; Simon 2013) of pre-trial defendants, those sentenced to community supervision or offenders released to parole.

Datafication, referring to processes of quantification and coding, is linked to technologies of prediction and pre-emption by producing datasets as inputs for real-time monitoring and analysis (Kaun and Stiernstedt 2019). As the earlier overview of smart prisons identified, the new digital technologies are harvesting detailed prisoner data: biometrics, emotional and behavioural patterns, mental health, vocal prints, realtime activities and movements; basically, surveillance of every micro aspect of a prisoner's quotidian existence. Kaun and Stiernstedt (2019: 12,17) observe that prisoners are the most 'surveilled, datafied and documented population[s]' and unable to opt out.

The apparatus of corrections has, along with law enforcement, incrementally expanded through database systems (Jefferson 2020) so that datafication is integral to furthering operational and logistical efficiencies in prisons while data-rich information underpins surveillance and control. It is arguable, perhaps, that the gathering and analysis of data can also benefit prisoners by feeding back into their individual programs of 
rehabilitation and study, positively informing management decisions (Knight 2018) and contributing to the normalisation of technologies in daily existence (Kaun and Stiernstedt 2019).

\section{Beneficial Technologies for Prisoners}

There is a flipside to the smart prison that might benefit prisoners: the rollout of secure personal digital communication devices. Contemporary technologies such as audiovisual links/videoconferencing facilities, digital tablets, iKiosks and in-cell computers can be considered improvements to the traditional shared prison landline telephone and slow postal services - that is, forms of communication that are largely obsolete outside prisons. Personal digital devices facilitate new ways to maintain family connections and opportunities to access justice and enable prisoners to undertake programs, study and develop their digital literacy. Whereas many of the smart prison technologies already discussed serve disciplinary, incapacitation and surveillant roles, the technologies to be discussed in this section may well serve positive changes, rehabilitation and help prisoners transition to post-release life in the outside world. The following focuses on personal devices rather than audiovisual link technologies typically used by prisoners to appear remotely in court or for legal conferencing (McKay 2018c).

The introduction of personal digital communication devices, computers and limited internet access has been controversial (Kerr and Willis 2018). The general public has frowned upon the supply of perceived luxuries to offenders, and popular punitivism suggests that prisons should be hard, austere and devoid of comforts (Johnson and Hail-Jares 2016); prisons should 'be seen to punish' (Moran, Jewkes and Turner 2016: 116). In addition, there have been security concerns regarding whether victims or witnesses may be harassed and whether offenders could continue to operate criminal activities from prison (Johnson and Hail-Jares 2016). Conceptually, the general public might expect prisons to be places of social banishment, but digital devices challenge the presumed impermeable nature of prison walls (McKay 2016). There is a considerable body of case law regarding whether prisoners can demand access to computers and the internet, especially when preparing for court appearances (McKay 2018a). At least in the Australian context, it seems that there are no enforceable rights for prisoners to access computers or devices, and even the common law right of access to justice is legitimately circumscribed by incarceration (McKay 2018a). However, Scharff Smith (2012) suggested that digital access is a human right and should be part of any normalised environment (Kaun and Stiernstedt 2020), while others have suggested that there may be the concept of 'digital rights' for prisoners (Lindström and Puolakka 2020: 14). Certainly, the internet is now recognised as a core social utility like water and electricity (Zients 2015).

The rehabilitative benefits of limited connectivity for prisoners are gradually being recognised in many countries. Jewkes and Reisdorf (2016) supported the provision of devices to prisoners to address digital illiteracy and access educational and rehabilitation programs. Provided that content is relevant to the particular jurisdiction and population and is of good quality, personal devices may be an excellent way to deliver transformative programs relating to violence, substance addiction, literacy/numeracy, vocational training, higher education (Hopkins 2015) and parental skills and to facilitate connection to post-release housing, health, financial support and employment services (Kerr and Willis 2018). Reisdorf and Rikard (2018) argued that successful rehabilitation models need to be integrated with models of re-entry and digital inclusion and provide both online and offline experiences. With this focus, smart prisons can then be considered less about incapacitation and more about enabling prisoners to develop self-direction and responsibility in preparation for re-entry into society.

There is a range of systems being rolled out, and personal devices have been evaluated in several countries (Van De Steene and Knight 2017). For instance, Lindström and Puolakka (2020) assessed the Smart Prison Project, including digital self-service devices, in Finnish prisons. They suggested that these devices can provide a cost-effective means of promoting rehabilitation and reducing recidivism by developing prisoners' autonomy, agency, self-esteem and life management skills that can improve the whole prison culture. They concluded that 'the more independent and interactive the digital self-services can be made, and the more "invisible" prison walls can become through digital means without taking security risks, the better for rehabilitation' (Lindström and Puolakka 2020:18). 
Palmer, Hatcher and Tonkin (2020) evaluated digital technology in prisons located in England and Wales. In addition to some of the benefits identified above, they found that access to in-cell telephone capabilities reduces the tensions among prisoners compared with shared wing telephones. We know that ongoing connection with loved ones is key to prisoners' welfare, and Johnson and Hail-Jares (2016) argued that personal devices might mean that prisoners are remote from their families but not altogether absent. Nurturing personal relationships are critical to prisoners and assist in producing positive outcomes through 'reducing their behavioral infractions, decreasing the risk of reoffending after release, and, for incarcerated parents who keep in touch with their children, lowering rates of depression, anxiety, and stress' (Digard et al. 2016: 4). However, it remains unclear whether video visitation via personal or shared devices confers these same benefits as in-person visits (Digard et al. 2016).

Personal digital technologies incentivise good behaviour because the threat of losing access to devices affects compliance (Knight 2016; McDougall et al. 2017). Overwhelmingly, Palmer, Hatcher and Tonkin (2020) found that digital technologies contribute to prisoners' psychological wellbeing, an increased sense of agency and autonomy and reduced tensions. There is, therefore, a small but growing body of evidence suggesting that digital devices can enhance a more rehabilitative environment-one that is more positive and hospitable with fewer frustrations between prisoners and staff, and one in which people in prison may experience a level of autonomy (McDougall et al. 2017).

There are, of course, concerns regarding digital devices. While the devices may provide a better way for prisoners to use their in-cell time (Kerr and Willis 2018), they might also result in prisoners spending excessive time in their cells. Johnson and Hail-Jares (2016: 286) discussed how various in-cell technologies, even radios and televisions, act as 'electronic babysitters'. However, prison authorities may appreciate the calming and sedating qualities of digital devices as efficient tools for offender management (Kaun and Stiernstedt 2020) or 'opiates of the masses' (Kharzraee and Unsworth 2012). There are also concerns that as data collection devices, there are security benefits for prison authorities in enabling more efficient monitoring of prisoners (Fabre and Zymaris 2016). A major concern is the commercialisation of prison communications (Jackson 2005; Kerr and Willis 2018) and resultant predatory pricing affecting a literally captive audience. Prisoners and sometimes their families pay well above the market for phone calls, video visits and other user-pays content (Digard et al. 2016; Johnson and Hail-Jares 2016; Palmer, Hatcher and Tonkin 2020). A final and key concern is that these devices will completely replace in-person contact visits from prisoners' families and lawyers. A glimpse of prison life devoid of outside human contact has been provided during the COVID-19 pandemic.

\section{Replacing Human Contact with Technologies: Coronavirus Jurisprudence}

As the COVID-19 pandemic took hold, prisons in Australia and other countries went into complete lockdown to minimise the risks of viral contagion among the enclosed prison populations; the state has responsibilities to care for the health and wellbeing of its prisoners. ${ }^{3}$ Prisons and other institutions of group living were acknowledged as 'particularly susceptible to the rapid spread of the COVID-19 virus' (Rakielbakhour v DPP: Hamill J, para 14). Given the transient and churning nature of prison populations, there were concerns expressed in England and Wales that there could be an 'explosive transmission of COVID-19 in congregate settings' as there had been on cruise ships (Coker 2020: 15). In the face of an impending health crisis, several jurisdictions implemented decarceration measures (Anthony 2020). ${ }^{4}$

Early on, the 'cascading effects on the criminal justice system' (El Nasher v DPP: Tinney J, para 42), the fact that 'the world changed considerably because of the COVID-19 pandemic' (R v Kelso: Norrish QC DCJ, para 3) and the anxieties about what might happen in prisons were recognised: 'it is fair to say that we in the criminal justice system are really all waiting with bated breath as we consider the possible impacts of this global pandemic if and when it hits the prisons' (DPP v Harper: Tinney J, para 40). A body of Australian 'coronavirus jurisprudence' has emerged from this time (Judicial College of Victoria n.d.) that highlights the substantial effects on the criminal justice system, procedure and prisons (see also The Public Defenders n.d.). 
By March 2020, it was clear that there might be increased burdens on prisoners due to the pandemic restrictions and 'more onerous conditions of incarceration' (Rakielbakhour v DPP: Hamill J, para 14). For instance, in the DPP v Calgaret in Victoria, Sexton J stated:

Since 21 March, all personal and family visits have been cancelled indefinitely. Contact legal visits have been suspended. Prisoner work is limited, meaning that there is limited opportunity to make money for highly valued telephone calls to family. There remains at present uncertainty (in terms of cost, access, and transport arrangements within prisons) regarding access to audio-visual facilities for prisoners to communicate with loved ones.

This highlights the lockdown's flow-on effects on prisoners' financial situations and how that has limited their ability to fund phone calls during a time of no contact visitation. Similarly, in NSW: 'since March 2020, all visits to inmates have been temporarily suspended, with telephone and audio-visual conferencing facilities made available instead' (RC v R; R v RC: Wilson J, para 219).

Custodial lockdown has not only affected prisoners' communications with the outside world, but has also become a live issue in decisions regarding liberty such as bail and sentencing. Hamill J, in a bail release application conducted in a 'virtual courtroom' (Rakielbakhour v DPP: para 13), reflected on the extraordinary circumstances that created a 'challenge for the criminal justice and penal systems of a kind not experienced in recent decades, if ever, in Australian law'. The court, in a now much-cited decision (Brown v R: para 48), was hesitant to 'express a general statement of principle regarding how this Court (and others) should deal with this crisis as regards its effect upon relevant sentencing principles'. The court did accept: 'that the situation is causing additional stress and concern for prisoners and their families, as it is for every member of the community. The extent to which that may be taken into account, if at all, will be a matter to be resolved on the particular facts of any individual case' (Brown v R: para 48; see also R v Nolan; R v Razzaghipour; Sazimanoska v R). Many courts have struggled with balancing competing interests: the need to incarcerate some people while acknowledging the increased risks of infection in a closed environment and additional stresses of custodial lockdown.

It was also during the pandemic that various prison authorities more closely examined the provision of personal digital devices as a means for prisoners to maintain connections with the outside world. For instance, Queensland Corrective Services (2020) introduced monitored 30-minute virtual personal visits with approved visitors via video links and a prisoner email service, and NSW commenced the rollout of detention-grade android tablet devices to prisoners (Fitzgerald 2020). While acknowledging the necessity to lockdown a vulnerable population during an extended period (and, ultimately, the general effectiveness in Australia of that strategy) and lauding the introduction of personal digital devices, it is still clear from the coronavirus jurisprudence that prisoners experienced amplified hardships, high levels of anxiety and increased isolation by the visitor lock-out. Australian coronavirus case law from 2020 provides a sense of prison life without physical contact visits because lawyers and family members were encouraged to use audiovisual links or 'video visits', prison telephones or postal services (Department of Justice and Community Safety-Corrections Victoria 2021; Guest v DPP: para 15). What knowledge is produced by analysing these decisions regarding the replacement of human contact with digital technologies?

\section{Family and Legal Visits}

Although correctional facilities have sought to make more audiovisual link technology available during the pandemic ( $\mathrm{R} v$ Razzaghipour), the loss of in-person family visits was felt by many prisoners. It is simply not the same. Courts recognised that 'to the extent that offenders have been able to access an audio-visual link visit ... it is of diminished quality and value compared to an in-person visit' (R v Razzaghipour: P Taylor SC DCJ, para 63). In DPP v Nguyen, the remandee submitted that since March 2020, his family had not been able to visit him personally, the video visits were of shorter duration than the earlier permitted physical contact visits and the videos did not enable the same degree of comfort as was derived from contact visits. It was noted in DPP v Kotiau that the lack of physical family visits would particularly affect a young, firsttime prisoner (see also Re Broes). In Re JK (para 23), Hollingworth J granted conditional bail, noting that 
the accused, who was legally a child at the time of the alleged manslaughter, could no longer see his family every week as was the custom throughout his time in custody:

True it is that the pandemic is forcing many families to communicate via phone or audio-visual links, but the effects of actual physical separation from family can be more acute for young persons than adults. Section 3B(1)(b) of the Bail Act expressly recognises the importance of strengthening and preserving such relationships in the case of accused who are children.

The prohibition on family visits to prison was held to render the remand of an Aboriginal bail applicant more onerous due to the recent loss of his sister and the grieving process (Re Kennedy). In DPP v Calgaret Sexton J remarked on how the restrictions would prevent visits from the prisoner's children (see also $\mathrm{R} \mathrm{v}$ Stott). In another bail application, general propositions regarding the pandemic's effects were discussed, including how the crisis 'may make time in custody very difficult and/or significantly more difficult than usual. Moreover, to the extent that correctional facilities are not permitting visitors, there may be greater isolation for those on remand' (Re Diab: Beach JA, para 38).

Isolation was a theme in Wyka \& Gardiner v R (para 144), in which the offender sought, unsuccessfully, to admit evidence regarding the effects of suspending personal visits: 'Ms Wyka's father usually visited her for about two hours each week. He does not have a landline telephone. So she calls him on his mobile phone, which is expensive, and limits the amount of time she can afford to speak to him'. As a result of the suspension of the intensive residential drug and alcohol treatment program and associated group meetings and her sporting and recreational activities, 'Ms Wyka feels isolated and depressed. She stays in her cell most of the day. Nightly lockdowns are earlier than they were and morning unlocking of cells occurs later' (Wyka \& Gardiner v R: Croucher AJA, para 148). Of course, the suspension of in-person visits has had no effects on prisoners who received none pre-pandemic (DPP v Singh).

In-person legal visits were also dramatically reduced or suspended ( $\mathrm{R} v$ Razzaghipour). In Guest v DPP, without providing formal evidence, counsel submitted that it took a week to organise a professional legal visit via audiovisual technology. In Re MM, with the cancellation of face-to-face visits, there was increased demand for audiovisual links and telephone facilities, limiting legal conferencing time. The court accepted that 'for people in prison, access to legal representatives is almost always more constrained than for people who are at large, and the constraints are undoubtedly greater under the current restrictions caused by the pandemic' (Re MM: Jane Dixon J, para 72). The pressures on the extant audiovisual link system for legal conferencing was also recognised in Rakielbakhour v DPP: Hamill J, para 15:

All legal visits in NSW prisons are being conducted by video-link. While the same is probably true of most conferences between lawyers and their clients, the facilities within the prison system must be under great strain because so many court cases are being conducted by video link and the number of available audio-visual suites is finite.

These circumstances were recognised as increasing stress and anxiety for prisoners who were often facing indefinitely postponed legal procedures leading to extended remand/incarceration (Re Tong; Thomas $\mathrm{v}$ Kitching). In Re Ashton (para 62), Elliott J considered whether the prison lockdown was a barrier to preparing an effective defence. While Corrections Victoria had arranged 'non-contact or box visits' for lawyers, Elliott J suggested that 'it may be more difficult to facilitate satisfactory interaction between the applicant and his defence team'. My own earlier research on prisoners' use of audiovisual links for legal conferencing supports the argument that confidentiality, communication and comprehension may be undermined (McKay 2018c).

\section{Mental Health}

The mental health implications of the COVID-19 restrictions have been highlighted in various decisions, and there is a recognised nexus between the absence of family contact visits as an additional hardship and how a prisoner's 'depression and anxiety will be exacerbated' by that absence (R v Despotovski: Haesler 
SC DCJ, para 39). The prohibition of family visits has been identified as adversely affecting prisoners' mental health and wellbeing (Bugmy Bar Book Committee 2020; Enggist et al. 2014). This is particularly so when, during the pandemic lockdowns, prisoners have also faced extended periods in their cells (Rakielbakhour v DPP). Expert reports presented before courts 'unsurprisingly, suggest that the lack of visits and other restrictions, such as the lack of rehabilitation services within the prison system due to the pandemic, are likely to have a deleterious effect upon the mental health of prisoners' ( $\mathrm{R} v$ Moananu: Buscombe DCJ, para 107). In Valentine v R, the court found that the necessary and effective steps taken by Corrective Services NSW to avoid the contagion nevertheless had negatively impacted inmates' wellbeing. Dr Ellis' expert forensic psychiatric report discussed the mental health effects: 'the general effect of measures to combat the spread of a virus (lockdowns, quarantines and reduction in face-to-face mental health staff presence) can induce new mental disorders, worsen existing mental disorders and reduce access to treatment' (Ellis 2020: 3). In addition, Dr Ellis argued that 'reduced access to visitors could increase distress in those with and without mental disorders ... the restrictions on service provision with suspended visits render persons with mental illness or cognitive impairment more at risk of worsening their pre-existing conditions. This could have a serious adverse effect on mental health' (Ellis 2020: 7-8). The Regional Office for Europe of the World Health Organization (2020: 8) suggested that decisions during the pandemic to restrict 'visits need to consider the particular impact on the mental well-being of prisoners and the increased levels of anxiety that separation from children and the outside world may cause'.

In DPP v Payne: para 58, Hogan J acknowledged that the offender was in a 'vulnerable psychological state' such that imprisonment was 'likely to be onerous', particularly with pandemic management necessitating 14 days quarantine isolation and ongoing restrictions, prohibitions on contact visits, limited out-of-cell hours to facilitate social distancing and reduced rehabilitative programs. As of July 2020, when there was no end in sight for the easing of restrictions in Victoria, Hogan J stated that it was appropriate to take these issues into account in sentencing given the increased risk of deteriorating mental health and the need to monitor the offender's depression, anxiety and suicidal ideation.

Anxiety and stress have been recognised as being amplified during the lockdown because there was a 'greater risk of contracting the virus, given that social distancing is so much harder to apply in prison, and more so, such problems have given rise to longer periods of lockdown and the reduction in the use of services and facilities for education and training in prison' (DPP v McDonagh: Parrish J, para 55). Evidently, there has been a complex of reasons for increased stress, including the sudden loss of rehabilitative programs. For instance, in R v Khoder (Elkaim J, para 12), the offender submitted that 'visitors were no longer permitted, restrictions had been placed on his capacity to be religiously observant and two of his rehabilitation programs had been cancelled'. Elkaim J responded:

Although the first two factors are important, I regard the interference with his rehabilitation as being particularly significant. As already mentioned, I previously regarded the offender to be a good candidate for rehabilitation so that the current restrictions may have a deleterious effect on the good work he has achieved so far. (R v Khoder: para 12)

The mental health effects of the COVID-19 lockdowns, isolation, lack of family visits and restrictions on therapy, education and sports programs have rippled through both adult correctional facilities as well as juvenile justice (Gordon, Klose and Lyttle Storrod 2021).

Where stringent restrictions have been implemented, they have, on the whole, been successful in containing the spread of the virus through prison populations. However, there have been disastrous situations; for example, in the US, it was reported that as of 12 January 2021, 343,008 prisoners had tested positive for COVID-19, and 2,144 had died (The Marshall Project 2021). In England and Wales, 71 prisoners had died of COVID-19 or COVID-19-related illnesses as of December 2020 (Grierson 2021). With the pandemic mostly under control in the wider community, prisons around Australia are aiming to open up again to personal, legal and cultural visits (see, e.g., Queensland Corrective Services 2020). However, what we can observe from the above coronavirus jurisprudence are some of the effects of reducing or 
eliminating pro-social, familial and professional connections and how already onerous custodial conditions can be exacerbated in that process.

The pandemic circumstances effectively prevented in-person 'social contact with family visitors and legal advisors', which has been recognised as an additional hardship in imprisonment ( $\mathrm{R} v$ Razzaghipour: $\mathrm{P}$ Taylor SC DCJ, para 65). Heightened anxiety and isolation have been common experiences, particularly in combination with the loss of therapeutic and rehabilitative programs and in circumstances of extant mental health issues. Therefore, the case law highlights the value of human connections in offender management, health and welfare, as well as access to justice (McKay 2017) and provides a glimpse of the adverse repercussions of replacing human contact with smart prison technologies.

\section{Discussion and Conclusion}

The insights from the coronavirus jurisprudence, combined with the digital criminological analysis and techno-social context (Brown 2006; Powell, Stratton and Cameron 2018), assist in critiquing the rise of the automated, smart or digital prison and reflecting on inequality, fairness and power (Lupton 2014) in technologised carceral sites. The Australian case law presents some of the repercussions of sealing off the closed environments of prison and prohibiting human contact with prisoners, including intensified mental health issues, heightened isolation and difficulties with instructing lawyers and preparing an effective defence. However, this is the direction that prison design is taking, prompting many questions: Do smart prisons empower a process of 'responsibilisation' or dehumanisation? Will smart prisons eliminate human contact or just change how it occurs? Do smart prisons provide a civilising process or a decivilising one (Hallsworth and Kaspersson 2017; Pratt 2013)? A major concern is: if there is a genuine goal of rehabilitation in contemporary corrections, how can this occur in an environment devoid of positive interactions between prisoners and other humans (Lindström and Puolakka 2020)?

Smart prison discourse refers to the goals of reducing recidivism and perhaps also increasing rehabilitation, but this feels almost tokenistic when the pre-eminent objectives appear to be incapacitation, operational efficiency and designing-out risk (Moran, Jewkes and Turner 2016). St John et al. (2019: 749) identified the incongruity between 'a professed goal of rehabilitation' and the realities of 'counter-rehabilitative' coercive environments. The positive contributions of increasing safety for prison officers and prisoners alike using new technologies are worthy; however, there needs to be a balance between the competing goals of security, efficiency and rehabilitation within a humane environment where technologies such as personal digital devices are normalised (Knight and Van De Steene 2019; Northfield 2018) and serve to complement rather than replace human contact.

There are multiple unexplored ethical and moral considerations (Knight and Van De Steene 2019) when the new panopticism and 'surveillance assemblages' (Moran, Jewkes and Turner 2016: 126) of a smart prison enable constant and intrusive surveillance and datafication of the prisoner's body and psychological state. Chances for privacy and, perhaps, even private thought and expression of the self are severely constrained and never out of the reach of penal power (Liebling and Crewe 2013). There is the possibility that technologies and surveillance can be overused, resulting in an imbalance between the respect for the inherent dignity of the human person versus the legitimate concern of security (Penal Reform International and Association for the Prevention of Torture [PRI and APT] 2015; United Nations 1976, 2015). For example, the indiscriminate and permanent use of surveillance technologies can result in an " "atmosphere of constant suspicion, paranoia, and self-conscious reflection", leading prisoners to suppress and lose touch with their identities' (PRI and APT 2015: 17). Life under a 'correctional microscope' (Bala and Trautman 2019: np), subject to hyper-visibility, can be 'psychologically highly invasive' (Liebling and Crewe 2013: 301) rather than rehabilitative.

As for technologies of automation that replace prison officers, PRI and APT (2015) argued that the lack of bilateral interaction between prison officers and prisoners may lead to the dehumanisation of detention. The automation and robotisation of prison management demonstrate an explicit jettisoning of the staffprisoner relational model and elimination of the variable and idiosyncratic human (Liebling and Crewe 
2013). Is this a model of debilitation over rehabilitation? Where will the human role models be to promote positive transformation? High-tech prisons can exaggerate social isolation and diminish mutual respect and reciprocity in human interaction, leading to increased tensions and frustrations expressed using anger and violence (Trammell, Rundle and Borrego 2021). Because technologies are increasingly embedded into prison infrastructure, there is a need to focus on the purposes of remand detention and custodial sentences and the relationship with prison design, policies and management. However, the experiences of the Japanese high-tech prison, Shimane Asahi Rehabilitation Center, that 'embraces rehabilitation, reentry and restorative justice', is said to possibly provide a more humane form of 'technocorrections' (Leighton 2014: 3-4). For instance, Leighton (2014) suggests that some technologies that replace human interactions have improved staff-prisoner relationships and minimised hostility (e.g., instead of degrading strip searches, drug 'sniffer' detection and body scans are used).

The intense and vast processes of datafication that smart prisons bring 'makes visible a dystopian version of the future' that ignores privacy and civil rights and leads in the direction of 'data injustice', according to Kaun and Stiernstedt (2019: 17). Aggregating data lakes of sensitive 'biometric, behavioral, and identifying information raises additional risks' regarding secure storage and future applications (Bala and Trautman 2019: np). Datafication emphasises historical behaviour, thus, contradicting conceptions of rehabilitation that focus on future transformations and positive changes (Kaun and Stiernstedt 2019: 19). Moreover, increased datafication and algorithmic decision-making ushers in the de-professionalised, dehumanised and automated prison (Kaun and Stiernstedt 2019: 19). Replacing human prison staff with AI ought not to be the objective in processes of smartification (Bala and Trautman 2019).

The seemingly favourable introduction of personal digital devices offers a more optimistic prospect. However, while personal communication technologies can positively empower prisoners to become more self-sufficient, responsible and digitally literate (Johnson and Hail-Jares 2016), prison authorities may need to temper this new-found agency and autonomy that could potentially undermine prison order and virtually breach prison walls. Digital communication technologies can make the prison more porous and permeable to the outside world (McKay 2016; Schept 2013) -less of a 'carceral archipelago' (Foucault 1977: 298), a 'not-so-total' total institution (Farrington 1992: 7; Goffman 1961), and less of a place of social exclusion (Jones 2000). Is it at this point that the smart prison fuses with the smart city to fully realise a vast, coherent and integrated Foucauldian carceral network (Foucault 1977)? More likely, the answer is that, undoubtedly, the extremities of prisoners' digital freedoms are already overwhelmed and utterly circumscribed by the smart prison. That is, the provision of personal digital devices to prisoners is a small concession to techno-sociality when compared with the might of pervasive, embedded prison surveillance, algorithms, analytics and datafication. The carceral automata arising in countries such as China, South Korea and Singapore-the prisons without guards, robots and technologised cells that relentlessly monitor the circadian processes of prisoners-are the 'scripted expressions of political-economic imperatives' (Moran, Jewkes and Turner 2016: 116) of twenty-first-century penality. In this process, we can perhaps see the emergence of a technocratic dream (Jefferson 2020) of the totalised digital prison regime.

\section{Acknowledgements}

I acknowledge the support of the Sydney Institute of Criminology's internship program, The University of Sydney Law School student, Claris Foo, for conducting the initial research and the further research assistance provided by The University of Sydney Law School student, Rodney Blake. In addition, I thank the anonymous reviewers for their instructive comments on the first draft of this paper.

Correspondence: Dr Carolyn McKay, Senior Research Fellow: The University of Sydney Law School; CoDirector: Sydney Institute of Criminology F10 New Law Building, The University of Sydney, NSW 2006 Australia. carolyn.mckay@sydney.edu.au 
1 See, e.g., the various public health instruments throughout 2020 and 2021 restricting gathering and movement: https://legislation.nsw.gov.au/information/covid19-legislation/gathering-and-movement

2 See, e.g., Crimes (Administration of Sentences) Regulation 2014 (NSW) reg 132.

${ }^{3}$ See, e.g., Public Health Regulation 2012 (NSW); Corrective Services Administrators' Council 2018.

${ }^{4}$ See, e.g., COVID-19 Legislation Amendment (Emergency Measures) Act 2020 (NSW).

\section{References}

Altay B (2020) Project on integration of smart technologies into prisons (ACEP). International Corrections \& Prisons Association, 7 July. https://icpa.org/project-on-integration-of-smart-technologies-into-prisons-acep/

Anthony T (2020) Coronavirus is a ticking time bomb for the Australian prison system. The Guardian, 26 March. https://www.theguardian.com/commentisfree/2020/mar/26/coronavirus-is-a-ticking-time-bomb-for-theaustralian-prison-system

Bagaric M, Hunter D and Wolf G (2018) Technological incarceration and the end of the prison crisis. Journal of Criminal Law and Criminology 108(1): 73-135. https://scholarlycommons.law.northwestern.edu/jclc/vol108/iss1/2/

Bala N and Trautman L (2019) "Smart" technology is coming for prisons, too. Slate, 30 April. https://slate.com/technology/2019/04/smart-ai-prisons-surveillance-monitoring-inmates.html

Barbour B (2012) Managing use of force in prisons: The need for better policy and practice. A special report to parliament under s.31 of the Ombudsman Act 1974. Sydney: NSW Ombudsman. https://www.ombo.nsw.gov.au/ data/assets/pdf file/0004/5971/SR CustodialServic es Use of force web Jul12.pdf

Beck U (1992) Risk society: Towards a new modernity. London: SAGE Publications.

Brown S (2006) The criminology of hybrids: Rethinking crime and law in technosocial networks. Theoretical Criminology 10(2): 223-244. https://doi.org/10.1177\%2F1362480606063140

Bugmy Bar Book Committee (2020) COVID-19: Risks and impacts on prisoners and communities. In Bugmy Bar Book Committee (eds) The Bugmy Bar Book. The Public Defenders.

https://www.publicdefenders.nsw.gov.au/Pages/public defenders research/barbook/pdf/BBP COVID19 chapter-July2020.pdf

Byrom N (2019) Digital justice: HMCTS data strategy and delivering access to justice. Surrey: The Legal Education Foundation. https://research.thelegaleducationfoundation.org/research-learning/funded-research/digitaljustice-hmcts-data-strategy-and-delivering-access-to-justice-report-and-recommendations

Carbone N (2011) South Korea rolls out robotic prison guards. Time, 27 November. https://newsfeed.time.com/2011/11/27/south-korea-debuts-robotic-prison-guards/

Chen S (2019) No escape? Chinese VIP jail puts AI monitors in every cell 'to make prison breaks impossible'. South China Morning Post, 1 April. https://www.scmp.com/news/china/science/article/3003903/no-escape-chinesevip-jail-puts-ai-monitors-every-cell-make

Coker R (2020) Expert report: COVID-19 and prisons in England and Wales. London: Howard League for Penal Reform and Prison Reform Trust, 31 March. http://prisonreformtrust.org.uk/portals/0/documents/COKER Report HL PRT.pdf

Corrective Services New South Wales (2017) The Bulletin January-February 2017, Issue 689.

Craig TR, Russo J and Shaffer JS (2016). Eyes in the skies: The latest threat to correctional institution security. Corrections Today: 46-51.

Department of Communities \& Justice (2019) Prison officers stamp out contraband. Department of Communities \& Justice, 12 June. https://www.justice.nsw.gov.au/Pages/media-news/media-statements/2019/prison-officersstamp-out-contraband.aspx

Department of Justice and Community Safety—Corrections Victoria (2021) Commissioner's requirements. https://www.corrections.vic.gov.au/commissioners-requirements-part-1

Digard L, diZerega M, Yaroni A and Rinaldi J (2016) A new role for technology? Implementing video visitation in prison. New York: Vera Institute of Justice. https://www.vera.org/publications/video-visitation-in-prison

Dodd S, Antrobus E and Sydes M (2020) Cameras in corrections: Exploring the views of correctional officers on the introduction of body-worn cameras in prisons. Criminal Justice and Behavior 47(9): 1190-1208. https://doi.org/10.1177\%2F0093854820942288

Donoghue J (2017) The rise of digital justice: Courtroom technology, public participation and access to justice. Modern Law Review 80(6): 995-1025. https://doi.org/10.1111/1468-2230.12300 
Ellis A (2020) Re: COVID-19 and mental health issues for NSW prisoners. Letter to Manea E, Legal Aid New South Wales, 9 April. https://www.publicdefenders.nsw.gov.au/Documents/dr-ellis-covid-19-mental-health-issuesfor-nsw-prisoners.pdf

Enggist S, Møller L, Galea G and Udesen C, eds (2014) Prisons and health. Copenhagen: World Health Organization. https://www.euro.who.int/en/health-topics/health-determinants/prisons-andhealth/publications/2014/prisons-and-health

Fabre R and Zymaris C (2016) Designing secure prisoner computer systems. North Carolina: Lulu Press.

Farrington K (1992) The modern prison as total institution? Public perception versus objective reality. Crime \& Delinquency 38(1): 6-26. https://doi.org/10.1177\%2F0011128792038001002

Feeley M and Simon J (1994) Actuarial justice: The emerging new criminal law. In Nelken D (ed.) The futures of criminology. London: SAGE Publications.

Fitzgerald B (2020) Tablet computers have kept prisoners in touch with family during COVID-19. ABC News, 21 November. https://www.abc.net.au/news/2020-11-21/tablet-computers-to-prisoners-during-covid$\underline{19 / 12895870}$

Foucault M (1977) Discipline and punish: The birth of the prison. New York: Vintage Books.

Francescani C (2019) US prisons and jails using AI to mass-monitor millions of inmate calls. ABC News, 25 October. https://abcnews.go.com/Technology/us-prisons-jails-ai-mass-monitor-millions-inmate/story?id=66370244

Gacek J (2020) In the era of e-carceration: Criminal justice trends and concerns with electronic monitoring. Annual Review of Interdisciplinary Justice Research 9: 32-56. https://www.academia.edu/42738234/In the Era of ECarceration Gacek

Ganesan D (2018) New technology on trial at Changi Prison can detect cell fights through video analytics. The Straits Times, 9 Oct 9. https://www.straitstimes.com/singapore/new-technology-on-trial-at-changi-prison-candetect-cell-fights-through-video-analytics

Goedbloed B (2019) Artificial intelligence in a prison environment. In Technology in Corrections Conference: Digital Transformation, Lisbon, 2-4 April: 1-17. International Corrections \& Prisons Association. https://icpa.org/library/tic19019-artificial-intelligence-in-a-prison-environment/

Goffman E (1961) Asylums: Essays on the condition of the social situation of mental patients and other inmates. Garden City: Anchor Books.

Gordon F, Klose H and Lyttle Storrod M (2021): Youth (in)justice and the COVID-19 pandemic: Rethinking incarceration through a public health lens. Current Issues in Criminal Justice 33(1): 27-46. https://doi.org/10.1080/10345329.2020.1859966

Grierson J (2021) Covid deaths in prisons in England and Wales rise by 50\% in a month. The Guardian, 13 January. https://www.theguardian.com/society/2021/jan/12/covid-deaths-prisons-england-wales-prisonerscoronavirus-cases

Grommon E, Carter J and Scheer C (2018) Quantifying the size of the contraband cell phone problem: Insights from a large rural state penitentiary. Prison Journal 98(5): 630-648. https://doi.org/10.1177\%2F0032885518794116

Halberstadt RL and La Vigne NG (2011) Evaluating the use of radio frequency identification device (RFID) technology to prevent and investigate sexual assaults in a correctional setting. Prison Journal 91(2): 227-249. https://doi.org/10.1177\%2F0032885511403594

Hallsworth S and Kaspersson M (2017) Punitivity and technology. In McGuire MR and Holt TJ (eds) The Routledge Handbook of Technology, Crime and Justice: 565-576. London: Routledge.

Hannah-Moffat K (2013) Punishment and risk. In Simon J and Sparks R (eds) The SAGE handbook of punishment and society. London: SAGE Publications.

Hayward KJ (2012) Five spaces of cultural criminology. British Journal of Criminology 52(3): 441-462. https://doi.org/10.1093/bjc/azs008

Hopkins S (2015) Ghosts in the machine: Incarcerated students and the digital university. Australian Universities' Review 57(2): 46-53. http://www.nteu.org.au/library/view/id/6468

Jackson SJ (2005) Ex-communication: Competition and collusion in the U.S. prison telephone industry. Critical Studies in Media Communication 22(4): 263-280. https://doi.org/10.1080/07393180500288329

Jefferson B (2020) Digitize and punish: Racial criminalization in the digital age. Minneapolis: University of Minnesota Press.

Jewkes Y and Reisdorf BC (2016) A brave new world: The problems and opportunities presented by new media technologies in prisons. Criminology \& Criminal Justice 16(5): 534-551. https://doi.org/10.1177\%2F1748895816654953

Johnson R and Hail-Jares K (2016) Prisons and technology: General lessons from the American context. In Jewkes Y, Bennett J and Crewe B (eds) Handbook on Prisons. London: Routledge. 
Jones R (2000). Digital rule: Punishment, control and technology. Punishment \& Society 2(1): 5-22. https://doi.org/10.1177\%2F14624740022227836

Judicial College of Victoria (n.d.) Coronavirus jurisprudence. https://www.judicialcollege.vic.edu.au/resources/coronavirus-jurisprudence

Kaun A and Stiernstedt F (2019) Doing time/time done: Exploring the temporalities of datafication in the smart prison. In Hartmann M, Prommer E, Deckner K and Görland SO (eds) Mediated time: Perspectives on time in a digital age: 129-147. Basingstoke: Palgrave Macmillan.

Kaun A and Stiernstedt F (2020) Doing time, the smart way? Temporalities of the smart prison. New Media \& Society 22(9): 1580-1599. https://doi.org/10.1177\%2F1461444820914865

Kenis P, Kruyen PM, Baaijens J and Barneveld P (2010) The prison of the future? An evaluation of an innovative prison design in the Netherlands. Prison Journal 90(3): 313-330. https://doi.org/10.1177\%2F0032885510373506

Kerr A and Willis M (2018) Prisoner use of information and communications technology.

Trends and Issues in Crime and Criminal Justice (560): 1. Canberra: Australian Institute of Criminology. https://www.aic.gov.au/publications/tandi/tandi560

Khair M (2018) A prison without guards: Where technology enhances operational effectiveness. Home Team NEWS, 6 July. https://www.mha.gov.sg/home-team-news/story/detail/a-prison-without-guards-where-technologyenhances-operational-effectiveness/

Kharzraee E and Unsworth K (2012) Social media: The new opiate of the masses? International Review of Information Ethics 18: 49-59. https://doi.org/10.29173/irie303

Kim L (2012) Meet South Korea's new robotic prison guards. Digital Trends, 21 April. https://www.digitaltrends.com/cool-tech/meet-south-koreas-new-robotic-prison-guards/

Knight V (2016) Remote control: Television in prison. Basingstoke: Palgrave Macmillan.

Knight V (2018) Developing digital strategies: Becoming a smart prison. In Workshop ICT in Prisons, Stockholm, 2224 May: 1-21. The European Organisation of Prison and Correctional Services. https://www.europris.org/file/presentations-ict-workshop-2018-22-25-05-stockholm/

Knight V and Van De Steene S (2017) The capacity and capability of digital innovation in prisons: Towards smart prisons. Advancing Corrections 4: 88-101. https://dora.dmu.ac.uk/handle/2086/16650

Knight V and Van De Steene S (2019) Ethical and moral reflections on the digital prison. Justice Trends, 19 July. https://justice-trends.press/ethical-and-moral-reflections-on-the-digital-prison/

Koslover R, Hung V, Babin S and Mills A (2016) Market survey on contraband detection technologies. Maryland: John Hopkins University Applied Physics Laboratory.

https://www.ncjrs.gov/App/Publications/abstract.aspx?ID=272853

Krasmann S (2017) Imagining Foucault. On the digital subject and “visual citizenship". Foucault Studies 23: 10-26. https://doi.org/10.22439/fs.v0i0.5339

Leighton P (2014) 'A model prison for the next 50 years': The high-tech, public-private Shimane Asahi Rehabilitation Center. Justice Policy Journal 11(1): 1-16. https://ssrn.com/abstract=2508510

Leung C (2019) Robot warders check on inmates as Hong Kong tests 'smart prison' devices to step up security, surveillance. South China Morning Post, 21 October. https://www.scmp.com/news/hong-kong/law-andcrime/article/3033791/robot-warders-check-inmates-hong-kong-tests-smart

Lewer N and Davison N (2005) Non-lethal technologies-an overview. In UN Institute for Disarmament Research (ed) Disarmament forum. 2005/1: Science, Technology and the CBW Regimes, UNDIR/DF/2004/5: 37-51. Geneva: UN Institute for Disarmament Research. https://programs.fas.org/bio/chemweapons/documents/Lewer\%20and\%20Davison.pdf

Liebling A and Crewe B (2013) Prisons beyond the new penology: The shifting moral foundations of prison management. In Simon J and Sparks R (eds) The SAGE handbook of punishment and society: 283-307. London: SAGE Publications.

Lindström B and Puolakka P (2020) Smart prison: The preliminary development process of digital self-services in Finnish prisons. International Corrections \& Prisons Association, 28 July. https://icpa.org/smart-prison-thepreliminary-development-process-of-digital-self-services-in-finnish-prisons /

Lupton D (2012) Digital sociology: An introduction. Sydney: University of Sydney. https://ses.library.usyd.edu.au/handle/2123/8621

Lupton D (2014) Digital Sociology. London: Routledge.

McDougall C, Pearson DAS, Togerson DJ and Garcia-Reyes M (2017) The effect of digital technology on prisoner behavior and reoffending: A natural stepped-wedge design. Journal of Experimental Criminology 13(4): 455-482. https://doi.org/10.1007/s11292-017-9303-5

McKay C (2016) Video links from prison: Permeability and the carceral world. International Journal for Crime, Justice and Social Democracy 5(1), 21-37. https://doi.org/10.5204/ijcjsd.v5i1.283 
McKay C (2017) Face-to-interface Communication: Accessing Justice by Video Link from Prison. In Flynn A and Hodgson J (eds) Access to justice and legal aid: Comparative perspectives on unmet legal need: 103-121. Oxford: Hart Publishing.

McKay C (2018a) Digital access to justice from prison: Is there a right to technology? Criminal Law Journal, 42(5), 303-321.

McKay C (2018b) Submission to the inquiry into Parklea Correctional Centre and other operational issues: Rapid build dormitory prisons, Submission No 17. Sydney: The University of Sydney. https://www.parliament.nsw.gov.au/lcdocs/submissions/59825/0017\%20Dr\%20Carolyn\%20McKay.pdf

McKay C (2018c) The pixelated prisoner: Prison video links, court 'appearance' and the justice matrix. London: Routledge.

McKay C (2020a) Glitching justice: Audio visual links and the sonic world of technologised courts. Law Text Culture 24: 364-404. https://ro.uow.edu.au/ltc/vol24/iss1/15

McKay C (2020b) Predicting risk in criminal procedure: Actuarial tools, algorithms, AI and judicial decision-making. Current Issues in Criminal Justice 32(1): 22-39. https://doi.org/10.1080/10345329.2019.1658694

McKay C (2021) Digital justice and video links: Connecting and conflating courtroom and carceral space. In Duncanson K and Henderson E (eds) Courthouse architecture, design and social justice: 181-201. London: Routledge.

Ministry of Justice (2019) Safety in custody statistics, England and Wales: Deaths in prison custody to June 2019, assaults and self-harm to March 2019. Ministry of Justice, 25 July. https://assets.publishing.service.gov.uk/government/uploads/system/uploads/attachment data/file/820627/ safety-in-custody-q1-2019.pdf

Moran D, Jewkes Y and Turner J (2016) Prison design and carceral space. In Jewkes Y, Bennett J and Crewe B (eds) Handbook on prisons: 114-130. London: Routledge.

Mulcahy L and Rowden E (2019) The democratic courthouse: A modern history of design, due process and dignity. London: Routledge.

Navtech Radar (n.d.) Drone detection. https://navtechradar.com/explore/drone-detection/

New South Wales Auditor-General (2019) Managing growth in the NSW prison population. Sydney: Audit Office of New South Wales. https://www.audit.nsw.gov.au/our-work/reports/managing-growth-in-the-nsw-prisonpopulation

New South Wales Government. https://legislation.nsw.gov.au/information/covid19-legislation/gathering-andmovement

Northfield R (2018) Prison tech: Keeping inmates and staff secure. The Institution of Engineering \& Technology, 15 February. https://eandt.theiet.org/content/articles/2018/02/prison-tech-keeping-inmates-and-staff-secure/

O’Malley P (1984) Technocratic justice in Australia. Law in Context 2: 31-49.

Palmer EJ, Hatcher RM and Tonkin MJ (2020) Evaluation of digital technology in prisons. Ministry of Justice. https://www.gov.uk/government/publications/evaluation-of-digital-technology-in-prisons

Paulo DA and Tanu E (2019) How Changi Prison is taking to video analytics and facial recognition in a big way. Channel News Asia, 25 February. https://www.channelnewsasia.com/news/cnainsider/singapore-changiprison-facial-recognition-ai-tech-surveillance-11263318

Penal Reform International and Association for the Prevention of Torture (2015) Balancing security and dignity in prisons: A framework for preventive monitoring. 2nd ed. London: Penal Reform International. https://cdn.penalreform.org/wp-content/uploads/2016/01/security-dignity-2nd-ed-v6.pdf

Powell A, Stratton G and Cameron R (2018) Digital criminology: Crime and justice in digital society. New York: Routledge.

Pratt J (2013) Punishment and 'the civilizing process'. In Simon J and Sparks R (eds) The SAGE handbook of punishment and society: 90-113. Thousand Oaks: SAGE Publications.

Queensland Corrective Services (2020) COVID-19 (Coronavirus) pandemic: Information for families of prisoners in Queensland. https://corrections.qld.gov.au/information-for-visitors-to-our-prisons-covid-19/

Regional Office for Europe of the World Health Organization (2020) Preparedness, prevention and control of COVID19 in prisons and other places of detention: Interim guidance. Copenhagen: World Health Organization. https://apps.who.int/iris/bitstream/handle/10665/336525/WHO-EURO-2020-1405-41155-55954eng.pdf? sequence $=1$ \&isAllowed $=\mathrm{y}$

Reisdorf BC and Rikard RV (2018) Digital rehabilitation: A model of reentry into the digital age. American Behavioral Scientist 62(9): 1273-1290. https://doi.org/10.1177\%2F0002764218773817

Roberts A (2020) Prison officers to wear body-worn cameras. NSW Government Department of Communities \& Justice, 18 February. https://www.dcj.nsw.gov.au/news-and-media/news/prison-officers-to-wear-body-worncameras 
Rossner M and McCurdy M (2020) Video hearings process evaluation (phase 2): Final report. HM Courts \& Tribunals Service. https://www.gov.uk/government/publications/hmcts-video-hearings-process-evaluation-phase-2final-report

Russo J and Wells D (2019) Contraband detection technologies: A market survey. Corrections Today: 14-17. https://www.ncjrs.gov/App/Publications/abstract.aspx?ID=274772

Scharff Smith P (2012) Imprisonment and internet-access: Human rights, the principle of normalization and the question of prisoners access to digital communications technology. Nordic Journal of Human Rights 30(4): 454482. https://www.researchgate.net/publication/321018740 Imprisonment and internetaccess Human rights the principle of normalization and the question of prisoners access to digital commun ications technology

Schept J (2013) 'A lockdown facility ... with the feel of a small, private college': Liberal politics, jail expansion, and the carceral habitus. Theoretical Criminology 17(1): 71-88. https://doi.org/10.1177\%2F1362480612463113

Schweitzer RC, Treado PJ, Olkhovyk O and Zbur L (2018) Automated chemical imaging identification of illegal drugs in correctional facilities mail. Journal of Chemometrics 32(10): e3038. https://doi.org/10.1002/cem.3038

Simon J (2013) Punishment and the political technologies of the body. In Simon J and Sparks R (eds) The SAGE handbook of punishment and society: 60-89. London: SAGE Publications.

Smith GJD, Bennett Moses L and Chan J (2017) The challenges of doing criminology in the big data era: Towards a digital and data-driven approach. British Journal of Criminology 57(2): 259-274. https://doi.org/10.1093/bjc/azw096

St. John VJ, Blount-Hill K-L, Evans D, Ayers D and Allard S (2019) Architecture and correctional services: A facilities approach to treatment. Prison Journal 99(6): 748-770. https://doi.org/10.1177\%2F0032885519877402

Sydes M, Dodd S and Antrobus E (2020) Body cameras behind bars: Exploring correctional officers' feelings of safety with body-worn cameras. Criminology \& Criminal Justice. Advance online publication. https://doi.org/10.1177\%2F1748895820959125

Tangen J (2018) What is digital criminology? In British Society of Criminology Midlands Regional Group Seminar 'Digital Criminology', De Montfort University, Leicester, 5 March.https://dora.dmu.ac.uk/handle/2086/16052

The Law Society Commission on the Use of Algorithms in the Justice System and The Law Society of England and Wales (2019). Algorithms in the criminal justice system. London: The Law Society of England and Wales. https://www.lawsociety.org.uk/en/topics/research/algorithm-use-in-the-criminal-justice-system-report

The Marshall Project (2021) A state-by-state look at 15 months of coronavirus in prisons. https://www.themarshallproject.org/2020/05/01/a-state-by-state-look-at-coronavirus-in-prisons

The POA (n.d.) PR 299: POA survey of work-related wellbeing. https://www.poauk.org.uk/news-events/newsroom/posts/2021/january/pr-229-poa-survey-of-work-related-wellbeing/

The Public Defenders (n.d.) COVID-19 resources for criminal lawyers. https://www.publicdefenders.nsw.gov.au/Pages/c19resources.aspx

Trammell R, Rundle M and Borrego AR (2021) Anger, frustration, and snitching: Inmates describe structured isolation in a high-tech prison. Deviant Behavior 42(9): 1067-1085. https://doi.org/10.1080/01639625.2020.1720936

Treloar C, McCredie L and Lloyd AR (2016) The prison economy of needles and syringes: What opportunities exist for blood borne virus risk reduction when prices are so high? PLOS ONE 11(9): e0162399. https://doi.org/10.1371/journal.pone.0162399

Van De Steene S and Knight V (2017) Digital transformation for prisons: Developing a needs-based strategy. Probation Journal 64(3): 256-268. https://doi.org/10.1177\%2F0264550517723722

Whitworth A (2010) Detecting contraband: Current and emerging technologies and limitations. Corrections Today: 105-107. https://nij.ojp.gov/library/publications/detecting-contraband-current-and-emerging-technologiesand-limitations

Wood MA (2021) Rethinking how technologies harm. British Journal of Criminology 61(3): 627-647. https://doi.org/10.1093/bjc/azaa074

Yang S (2020) Taiwan's first 'smart prison' unveiled. Taiwan News, 4 December. https://www.taiwannews.com.tw/en/news/4067777

Yusof A (2018) Changi Prison raises tech bar with automated checks, surveillance system that detects fights. Channel News Asia, 22 June. https://www.channelnewsasia.com/watch/changi-prison-raises-tech-barautomated-checks-surveillance-system-detects-fights-video-1544246

Zients J (2015) Delivering on broadband opportunity. The White House, 21 September. https://obamawhitehouse.archives.gov/blog/2015/09/21/new-steps-deliver-high-speed-broadband-acrossunited-states 


\section{Australian Case Law}

Astbury v R (No 2) [2020] VSCA 158 (18 June 2020).

Brown $v$ R [2020] VSCA 60 (23 March 2020).

DPP v Calgaret [2020] VCC 673 (4 May 2020).

DPP v Harper (a pseudonym) [2020] VCC 336 (22 March 2020).

DPP v Kotiau [2020] VSC 245 (7 May 2020).

DPP v McDonagh [2020] VCC 760 (1 June 2020).

DPP v Nguyen [2020] VCC 639 (22 May 2020).

DPP v Payne [2020] VCC 1036 (17 July 2020).

DPP v Singh [2020] VCC 719 (26 May 2020).

El Nasher v DPP [2020] VSCA 144 (4 June 2020).

Guest v DPP [2020] VSC 218 (17 April 2020).

$R v$ Despotovski [2020] NSWDC 110 (15 April 2020).

$R v$ Khoder (No 2) [2020] ACTSC 76 (14 April 2020).

$R v$ Kelso [2020] NSWDC 157 (17 April 2020).

$R v$ Moananu [2020] NSWDC 672 (5 November 2020).

$R v$ Nolan [2020] VSC 416 (10 July 2020).

$R v$ Razzaghipour; $R v$ Rixon; $R v$ Charbel [2020] NSWDC 882 (17 September 2020).

$R v$ Stott (No 2) [2020] ACTSC 62 (23 March 2020).

Rakielbakhour v DPP [2020] NSWSC 323 (31 March 2020).

$R C v R ; R v R C$ [2020] NSWCCA 76 (22 April 2020).

Re Ashton [2020] VSC 321 (27 April 2020).

Re Broes [2020] VSC 128 (19 March 2020).

Re Diab [2020] VSC 196 (21 April 2020).

Re JK [2020] VSC 160 (1 April 2020).

Re Kennedy [2020] VSC 187 (17 April 2020).

Re MM [2020] VSC 691 (20 October 2020).

Re Tong [2020] VSC 141 (26 March 2020).

Sazimanoska v R [2020] VSCA 66 (26 March 2020).

The State of Western Australia v Edwards (No 7) [2020] WASC 339 (24 September 2020).

Thomas v Kitching [2020] VSC 206 (23 April 2020).

Valentine $v R$ [2020] NSWCCA 116 (4 June 2020).

Wyka \& Gardiner v R [2020] VSCA 104 (1 May 2020).

\section{Legislation and Guidelines}

Crimes (Administration of Sentences) Regulation 2014 (NSW).

Corrective Services Administrators' Council (2018) Guiding principles for corrections in Australia. Revised. https://www.corrections.vic.gov.au/guiding-principles-for-corrections-in-australia

Public Health Regulation 2012 (NSW).

United Nations (1976) International Covenant on Civil and Political Rights. https://www.ohchr.org/EN/ProfessionalInterest/Pages/CCPR.aspx

United Nations (2015) United Nations Standard Minimum Rules for the Treatment of Prisoners (the Mandela Rules). UN-Doc A/C.3/70/L.3. https://undocs.org/A/C.3/70/L.3 